\title{
Standard Education Using SWOT Analysis
}

\author{
A A Rosiah ${ }^{1}$, Sukarmin $^{2}$, Sarwanto $^{3}$ \\ ${ }^{1}$ College Student of Magister Physics Education, University of Sebelas Maret \\ ${ }^{2}$ Lecturer of Magister Physics Education, University of Sebelas Maret \\ \{arumangger@student.uns.ac.id ${ }^{1}$, sukarmin67@staff.uns.ac.id², sarwanto@fkip.uns.ac.id ${ }^{3}$ \}
}

\begin{abstract}
The purpose of this research is (1) Knowing the Implementation of 8 National Standards in senior high school in Pemalang (2) Providing Feedback based on the findings on the application of 8 National Education Standards to Improve the quality of education at Senior High School in Pemalang. This research is qualitative descriptive research. The type of research is case study. The data used is Primary data. Data collection techniques used were interviews and documentation. Data validity technique is Triangulation Source and data analysis technique used is approach of Strengths, Weakness, Opportunities, and Threats (SWOT Analysis). The conclusions of this study are (1) Strength in the implementation of 8 National Standard Education at senior high school in Pemalang is the school has planned, implemented and evaluated most of the indicators in compliance with the National Education Standards. (2) Weakness (weakness) in the implementation of National Standards Education is limited budget and fund has not been fulfilled ideally in facilities and infrastructure. (3) Opportunities in the implementation of 8 National Standards Education are schools trying to provide workshops and training to educators and educational staff to improve the quality of school education, and planning, financing implementation and evaluation of good budgeting have a positive impact on all elements school operations and school infrastructure. (4) Threats in the implementation of 8 National Standards Education is planning, socialization, implementation and evaluation and follow-up which not executed with good management in fulfillment of National Standard of Education will hamper the implementation and improvement of school education quality. (5) The results of the implementation of National Education Standards using SWOT analysis show that Strength is greater than the Weakness and Opportunities greater than Threat, which means the National Education Standard has been fulfilled.
\end{abstract}

Keyword: Standard Education, Analysis implementation, SWOT analysis

\section{INTRODUCTION}

Indonesia places education as a priority in development. In fact, the development of education takes place continuously over time. This is understandable because education today is a primary need that must be fulfilled by society. According to Purnomo (2016: 18), education today is a basic needs of society that aims to support development but also aims to improve the quality of human resources. 
The rapid development of human resources quality due to various problems in it, including issues in education. In Indonesia, education problems faced by the nation are complex. Paul Suparno in Drost J., (2005, p. Xix in Lubis, 2005: 2) summarizes the complexity of the problem in three aspects, namely the quality of education, equity of education and management. From the aspect of the quality of education, several important indicators that influence the curriculum, educational content, learning and evaluation process, teacher quality, educational facilities and infrastructure, and books. In the equity of education there are striking gaps among the nation's children. An example of such a gap is the Ministry of National Education data showing that there are still some 4.9 million children of learning age who have not had the opportunity to obtain primary and secondary education. Meanwhile, some Indonesian children are able to get the Olympic Physics medal (Kompas, 5 April 2005). On the aspect of management, education is faced with the question of autonomy, financing, bureaucracy and regulations that are also related to politics, ideology, economy and business. In the midst of these complex issues of education, the government established Government Regulation (PP) number 19 of 2005 on National Education Standards (SNP) and National Education Standards Board (BSNP). Currently, the PP has been amended to Government Regulation No. 32 of 2013 on national education standards. Every regulation on education is made in order that the management of education goes according to the direction and has the intended purpose. SNP aims to guarantee the quality of national education in the intellectual life of the nation and form the character and civilization of a dignified nation (Kompas, 17 May 2005 \& Final Draft: RPP SNP, Balitbang-MoNE, 2005).

National Education Standards are the minimum criteria of the education system throughout the jurisdiction of the Unitary State of the Republic of Indonesia (PP No. 32 of 2013). National Education Standards serve as a foundation in the planning, implementation, and supervision of education in order to realize a quality national education. And aims to ensure the quality of national education in order to educate the nation's life and shape the character and civilization of a dignified nation. To maintain consistency of the functions and objectives, the curriculum, learning process, and managerial as a whole must be referring to and based on the National Education Standards.

One high school that stands in the city of Pemalang is SMAN 1 Comal located in Manahan. SMAN 1 Comal is a school with a good quality image in the eyes of society, and good quality in the eyes of this society will be strengthened with the results of research. From the above problems, the authors feel interested in conducting research with the title "Analysis of Application of 8 National Standards of Education In SMAN 1 Comal - Pemalang".

\subsection{Research Method}

The study of this case study took place at SMAN 1 Comal in odd semester of academic year 2018/2019, which is located at Adi Sucipto Street no. 1, Manahan, Pemalang, which is under the auspices of the Education Office of Pemalang City. Time of Research The study took place in odd semester in October 2018.

This research uses descriptive qualitative research design to know the Implementation of National Standard of Education in order to improve the quality of education in Pemalang city. This research used qualitative descriptive analysis technique. Qualitative Descriptive Analysis is to provide a review or interpretation of the data obtained so that it becomes clear and meaningful compared with just the numbers. The steps are data reduction, data presentation with charts and text, then drawing conclusions. The type of research conducted is case study research. 
According Sugiyono (2013: 23), data on qualitative research that is in the form of personal documents, field notes, speech and actions of resource persons, documents, and others. This study uses primary data. Primary data is data obtained or collected directly from the object of research by the person doing the research. Primary data is also called original data or new data. Primary sources are data sources that directly provide data to the data collector (Sugiyono, 2013: 308). The primary data that will be obtained are standard data of content, standard process data, graduate competency standard data, data of educator and education personnel, standard of facilities and infrastructure, management standard, financing standard and assessment standard happened in academic year 2018/2019 and school's profile.

Interviews are used to know things from the source in more depth (Sugiyono, 2013: 317). Interview is a meeting of two people to exchange information and ideas through tana jwab, so it can be constructed meaning in a particular topic. Parties interviewed in this research are one of the teachers of senor high school in Pemalang.

Document is a record of events that have passed (Sugiyono, 2013: 329). Documents may take the form of diaries, pictures, photos, sketches, video documentation, and more. From the above understanding of experts concluded that the documentation is the collection of data related to the internal school that uses the School Self-Evaluation (EDS) and School Work Plan (RKS) (Cahyono et al, 2015: 101).

Qualitative data should use data validity techniques before analysis is done so that data is completely valid. Findings or data can be declared valid if there is no difference between the researchers reported with what actually happened to the object under study (Sugiyono, 2013: 365). Checking data is an important part of the research cycle because it is the process of convincing the reader that the data the author finds is completely legitimate. Efforts that can be taken by the researcher to obtain the validity of the research findings is to examine the credibility of the findings by using extension techniques in the field, deepened observation, triangulation (using multiple sources, methods, researchers, theory), peer discussions, tracking the conformity of results and checking members (Wahidmurni, 2008: 47). Data validity technique used in this research is source triangulation method, that is using various data source like document, archive to compare with result of interview with teacher of SMAN 1 Comal Pemalang.

Data analysis in qualitative research conducted since before entering field, during in field, and after finished in field. Nmun, more focused during the process in the field along with data collection (Sugiyono, 2013: 336). This research uses SWOT analysis and Importance Performance Analysis. SWOT analysis is one approach to describe the condition and evaluate a problem, project or business concept based on internal factors (inside) and external factors (outside) that is Strengths, Weakness, Opportunities, and Threats. Based on Kotler and Keller (in Bob Sabran, 2009: 57) The Importance Performance Analysis determines the ranking of various elements of the service group and identifies what action is required. Analysis of Importance Performance Analysis in this research is used to know the position of school according to the result of strength, weakness, opportunity and threats.

Cartesius SWOT diagram

\subsection{Results and Discussion}

All of the basic framework and curriculum structure in SMAN 1 Comal have been referring to permendikbud No.21 of 2016. The curriculum was developed using BSNP guidance taking into account local characteristics, socio-cultural surroundings, quality of learners. The curriculum shows the time allocation, remedial program plan, and enrichment 
for students. The curriculum also includes a program of self-development activities, either through counseling or extra-curricular counseling. The school already has a curriculum development team, therefore annually the curriculum evaluation is conducted. The process of preparing the content standards with regard to the above indicators, schools should provide counseling and guidance services to meet the personal development needs of learners. The learning load for class X and XI is 42 hours per week, while for class XII the study load is more than 42 hours, which is 45 hours due to the learning activities outside KBM at hours 0 and 9. KBM in accordance with effective week ( 52 weeks per year).

Educators in SMAN 1 Comal have developed learning plans ranging from Prota, Promes, Syllabus and RPP in accordance with the instructions that have been conveyed by the Principal assisted by the vice principal of curriculum. School has a syllabus document covering all subjects issued by kemendikbud. RPP has been made according to the reference of kemendikbud, but the learning method used is still less varied. From the observation of teachers teaching in class, the teacher still uses conventional way and not utilize the media optimally, this is due to time constraints. The number of learners per study group is 32 students. At the time of observation the teacher has drawn motivation to the students and restart the previous meeting material. However, in general the learning activities have not been referring to $5 \mathrm{M}$, but it is in accordance with the stages Most educators still use the lecture method in implementing the learning but not a few who have implemented innovative learning methods, one of them using IT-based learning media. The preparation of the lesson plan has taken into account gender differences, early abilities, intellectual stages, interests, talents, learning motivation, potential, social skills, emotional, learning styles, special needs, learning speed, cultural background, norms, values, and environment of learners.

The school has established a KKM based on the analysis of the complexity of the subjects, intek (input from students, that is, the students' initial ability) and the school support capacity. All the KKM subjects are already 70 . The policy of the school allows the teachers of the study to determine their own KKM may be more than 70 but should not be less than 70 . For the subject of physics, KKM set 80 in grade XII. This is because the demands from the government as support to students to pass in SNMPTN. Learners show better progress in achieving the target set by SKL each year, as evidenced by the graduation rate that reaches $100 \%$ in the academic year 2018/2019 but the values tend to be inconsistent. the achievement is not easy, the School facilitates the learners to improve learning outcomes through enrichment program, the School facilitates the increase of the UN value by increasing the hours of study outside the effective hours of school and holding the UN test subjects every Monday at the time outside of lesson time.

Self-development programs to develop the personality, life skills, religious and cultural values of learners have been done through the development activities of students' personalities in the form of Religious, Scouting, Flag Ceremony and counseling. But not all learners are personable in accordance with the values and norms that apply in the school environment and community environment, Some learners still behave in accordance with the habits prevailing in their environment, although the habit is less precise in the world of education. Schools always facilitate learners to develop personality, life skills, religious values and culture.

SMAN 1 Comal Pemalang has educators totaling 69 people, this number has met the predetermined standards. The educator's teachers have qualified teachers as follows: S1 certified as many as 58 people with $84.06 \%$ percentage, S2 certified as many as 11 people with a percentage of $15.94 \%$. From the above data, the competence of teachers has met the standards, and the development of competence is always facilitated by schools to improve 
qualifications and improve the competence of school principals and educators / teachers on an ongoing basis.

The determinants of good quality of education are determined by good learning process but also the comfort factor of the infrastructure that support the establishment of good quality of education. The land area of SMAN 1 Comal Pemalang with 1 floors building for 35 classes is $25,305 \mathrm{~m}^{2}$. The condition of the school meets the national standard, especially the classroom, the library, the biology laboratory, the physics laboratory, the chemistry laboratory, the computer laboratory, the teacher room, the leadership room, the administrative room, the counseling room, the UKS room, the organizational room, playground / sports, places of worship. However, the classrooms have not been equipped with a hand wash, educational equipment in the laboratory has not been used optimally and there is only 1 laboran to handle 3 laboratories at once. Schools also do not have a complete passive protection system and active against the dangers of lightning and fire.

Schools have clear vision, mission and objectives, which have been implemented in both RKS and RKAS. RKS and RKAS have been created by principals, teachers, TU staff, and school committees and have been endorsed by the education office of the city of Pemalang. However, it has not been socialized to all school residents and has not held periodic review of RKS and RKAS. However, the implementation of the vision and mission in the school development plan has not been optimal.

School has implemented cost management in accordance with the criteria. Schools have allocated funds for operational costs. Schools are digging up the source of fees from parents of learners and the government, there is help for the Poor Family (Gakin) which amounts to 20\% of the total students. Poor families are not charged (SPP $=0$ rupiah). Schools have an annual operational work program and manage and utilize funds from various sources. Schools always make accountable and transparent accountability reports.

All RPPs already include assessment activities and programs. Instrument assessment of learning outcomes used by educators already meet the requirements of substance, construction and Language, but the implementation in learning activities has not been optimal. The attitude assessment is done by looking at the most positive and the most negative student attitudes, for the average student (without complaint) being equally considered. Skill assessment is still rarely implemented because of the rarity of practicum and other activities that can improve student skills. Schools also conduct assessments with various techniques, forms, and assessment types, although not yet optimal. Assessment of the achievement of basic competence of learners is done by indicator. By using tests and non tests in written or oral form, performance observation, attitude measurement, assessment of work in the form of tasks, projects or products, using porto folio and self-assessment [11].

\section{CONCLUSIONS}

From the research findings, the conclusions of this study are: (1) Strength in the implementation of 8 SNPs in SMAN 1 Comal is the school has planned, implemented and evaluated most of the indicators in the fulfillment of National Education Standards. (2) Weakness (weakness) in the implementation of 8 SNPs in SMAN 1 Comal is limited budget and fund has not been fulfilled ideally in facilities and infrastructure. (3) Opportunities in the implementation of 8 SNPs in SMAN 1 Comal are schools trying to provide workshops and training to educators and educational staff to improve the quality of school education, and planning, financing implementation and evaluation of good budgeting have a positive impact on all elements school operations and school infrastructure. (4) The results of Threats analysis 
(Threats) in the implementation of 8 SNPs in SMAN 1 Comal are planning, socialization, implementation and evaluation and follow-up which is not executed with good management in fulfillment of National Education Standards will hinder the implementation and improvement of school education quality. (5) The results of the implementation of National Education Standards in SMAN 1 Comal using SWOT analysis show that Strength is greater than the Weakness and Opportunities greater than Threat, which means the National Education Standard has been fulfilled.

\section{REFERENCES}

[1] Asri Lubis. 2005. Implementation of National Standards in Education. Medan: Unimed.

[2] Bob Sabran. 2009. Marketing Management. Erland: Jakarta.

[3] Cahyono, Luki Eko et al. 2015. Analysis of Application 8 National Standards of Education at SMP Negeri 2 Dolopo Madiun Regency ASSETS: Journal of Accounting and Education Vol.4 No.2, October 2015. Madiun: IKIP PGRI Madiun.

[4] Kompas, February 15, 2005: School Collection for UN.

[5] Kompas, May 17, 2005: PP BNSP Finally signed by President, Kumaniora, p. 9.

[6] Kompas, May 3, 2005: Compulsory Education Fund for Private-Owned Countries, Humanities, p.9

[7] Government Regulation No. 32 of 2013 on National Education Standards. 2005. Jakarta: Depdiknas.

[8] Purnomo, Abdirachmat. 2016. Journal of Hanata Widya September 2016 Edition. Yogyakarta: Yogyakarta State University.

[9] Sugiyono. 2013. Educational Research Methods. Bandung: Alfabeta.

[10] Wahidmurni. 2008. Classroom Action Research: From Theory Towards Practice, along with examples of PTK results. Malang: UM Press.

[11] K. Saddhono, "Cultural and social change of foreign students in Indonesia: The influence of Javanese Culture in Teaching Indonesian to Speakers of Other Languages (TISOL)." IOP Conf. Ser.: Ear. and Envi. Sci.. vol. 126 no. 1 IOP Publishing, 2018. 